\title{
Children's Right to Family Life and the Swedish Constitution
}

\author{
Johanna Schiratzki
}

The Swedish Constitution, in chapter 1, section 2 of the Instrument of Government, imposes a duty on the Swedish State to work positively to protect each individual's right to privacy and family life. The Constitution states as follows: 'The public institutions shall promote the ideals of democracy as guidelines in all sectors of society and protect the private and family lives of the individual'.2

The Swedish Constitution further includes a dedicated provision for children in chapter 1 , section 2 of the Instrument of Government. ${ }^{3}$ This provision is not enforceable but provides general aims and ambitions for the governance of children (and adults) in Swedish society. ${ }^{4}$ The link between the Swedish Constitution and human rights has been described as too complex to summarise briefly. ${ }^{5}$ There is no doubt, however, that the understanding of chapter 1 , section 2 of the Instrument of Government is closely connected to human rights as expressed in conventions from European Union, the European Council and the United Nations. ${ }^{6}$ Three human rights instruments with a strong bearing on the constitutional right to family are, therefore, the Charter of the European

1 Approved by the Ethical board of Stockholm 17-05-2018. Registration number 2018/704-31-5.

2 Translated in Magnus Isberg, The Constitution of Sweden The Fundamental Laws and the Riksdag Act (Riksdagen 2016). See Titti Mattsson, 'Constitutional Rights for Children in Sweden' in Trude Haugli and others (eds), Children's Constitutional Rights in the Nordic Countries (Brill 2019).

3 Legislative Bill 2009/10:80 (Sw. Prop. 2009/10:80 En reformerad grundlag).

4 Legislative Bill 1975/76:209 (Sw. Prop. 1975/76:209 om ändring i regeringsformen) 32.

5 Lena Marcusson, 'Det offentliga uppdraget och de mänskliga rättigheterna' in Anna-Sara Lind and Elena Namli (ed), Mänskliga rättigheter $i$ det offentliga Sverige (Studentlitteratur 2017) 33 .

6 Chapter 10, section 6 Instrument of Government; chapter 2, section 19 Instrument of Government; chapter 10, section 1-2 Instrument of Government.

(C) JOHANNA SCHIRATZKI, 2020 | DOI:10.1163/9789004382817_019

This is an open access chapter distributed under the terms of the CC-BY-NC 4.0Licenseschiratzki - 9789004382817 
Union, the European Convention on the Fundamental Human Rights and Freedoms (ECHR) and the United Nations Convention on the Rights of the Child (CRC). ${ }^{7}$ Article 7 of the Charter of the European Union is identical to article 8.1 of the ECHR. Children's right to privacy and family life is further protected by the CRC, foremost by articles 16, 7 and 9 as well as articles 18, 20 and 21 .

The right to privacy and family life is a so-called negative right, as well as a positive right. ${ }^{8}$ It imposes a duty on the State not to intervene in family life and to afford protection against violence from non-State actors. ${ }^{9}$ The State may intervene in family life only if such an intervention is in accordance with the law. An intervention must also be considered necessary in a democratic society in the interests either of national security, public safety or the economic wellbeing of the country, for the prevention of disorder or crime, for the protection of health or morals, or for the protection of the rights and freedoms of others. The last ground - for the protection of the rights and freedoms of others - is frequently applied with regard to interventions in the family life of children. States also have positive obligations to secure respect for private and family life under article $8 \mathrm{ECHR} .{ }^{10}$ The State's duty to secure respect for private and family life is crucial in relation to migration law and family reunification. Recent temporary amendments of the Swedish migration law and related enactments have been considered a non-proportional infringement of the right to family life child according to article 8 ECHR. ${ }^{11}$

As a consequence of the dual nature of the right to protection for family life, the requirement of legality and the obligation to promote the best interests of the child, a multitude of legal acts relating to the protection of the family life of children have been passed by the Swedish legislator. The legal activity further points to the fact that the right to family life has a bearing on virtually all areas

See Louise Dane, 'Europadomstolen och barnets bästa' (2015) 2 Förvaltningsrättslig tidskrift 193-224; M. Grahn-Farley, 'Högsta domstolens rättighetspraxis från 2003 till 2015: utmaningar och möjligheter med en inkorporering av Barnkonventionen' (2017) Europarättslig tidskrift $65^{-669}$.

8 ECtHR, Guide on article 8 of the European Convention on Human Rights: Right to respect for private and family life, home and correspondence (Updated on 31 August 2018) 9, with reference to Kroon and Others $v$ the Netherlands App no 18535/91 (ECtHR, 27 October 1994) para 31. <https://www.echr.coe.int/Documents/Guide_Art_8_ENG.pdf> accessed date Month year.

$9 \quad$ Eg Case of Hajduová v Slovakia App no 266o/o3 (ECtHR, 30 November 2010), para 46.

10 Guide on article 8 of the European Convention on Human Rights (n 8) 9, with references to Lozovyye v. Russia App no 4587/og (ECtHR, 24 April 2018) para 36, Evans v the United Kingdom [GC] App no 6339/o5 (ECtHR, 10 April 2007) para 75, and Marckx v Belgium App no 6833/74 (ECtHR, 13 June 1979).

11 The Migration Court of Appeal, no 5407-08. 2018:20, 13 November 2018. 
of child law - given the child's need for care and protection as well as guidance for autonomy and participation. Some of these aspects, such as regulations on paternity and out-of-home care relate to the question of who are considered a child's legally recognised parents and who may be considered as de facto parents. According to the case law of the European Court of Human Rights (ECtHR), children's family consists of persons with ipso jure recognised positions as parents as well as de facto family members. For defining a de facto family, the existence of an emotional attachment and close personal ties are key. ${ }^{12}$ As will be discussed below, the existence of de facto family relation may trump legally recognised family relations. There is a tension between the two concepts of construing a family in that the fundamental part of the right to family life is the right to live together so that family relationships may develop normally. If this is the case, and a child lives with his or her legally recognised parents and family relations develops normally, the child's legally recognised parents are also de facto parents. ${ }^{13}$ A child may, however, develop de facto family ties to adults who are not legally recognised parents. For this to happen the child's right to family life understood as living together with de facto parents is either not fulfilled or extended. The first case would be when the child is not living with his or her legally recognised parents and, therefore, does not have a close personal tie to them. In the second case, a child could be living with the legally recognised parents as well as other persons. This could be, for example, a partner to a legally recognised parent living with the child or children living together as siblings.

Although children's right to family life has a bearing on virtually all areas of child law, this chapter is primarily limited to a discussion on the right to family life of the child with regard to the establishment of a family, either by a child's birth, adoption, custody or care-arrangement. These questions are not expressively covered by the Swedish Constitution. ${ }^{14}$ They are, however, covered by article 7.1 of the CRC, which states as follows:

The child shall be registered immediately after birth and shall have the right from birth to a name, the right to acquire a nationality and as far as possible, the right to know and be cared for by his or her parents.

12 Guide on article 8 of the European Convention on Human Rights (n 8) 46, with references to Paradiso and Campanelli $v$ Italy [GC] App no 25358/12 (ECtHR, 24 January 2017) para 140.

13 Marckx v Belgium (n 10) para 31; Olsson v Sweden (no. 1) App no 10465/83 (ECtHR, 24 March 1988) 59 .

14 See Legislative Bill 2009/10:80 (En reformerad grundlag). Swedish Government Official Reports 2008:125 SOU 2008:12(En reformerad grundlag del 1) 451 refers to the protection offered in legislative acts such as the Parental Code and the Social Services Act. 
The last phrase to 'be cared for by his or her parents' is in the case law of the European Court of Human Rights, often expressed as 'the mutual enjoyment by parent and child of each other's company'. ${ }^{15}$ It is presumed to constitute a fundamental element of family life. The aim of this article is to give an overview of a child's right to know and be cared for by his or her parents - be it birth-parents, adoptive parents, divorced parents, step-parents, foster parents or institutions ${ }^{16}$ - in the light of the Swedish Constitution, recent legislation and case law. To set the scene, some characteristics of Swedish society are sketched in the next section.

When family life in Sweden is presented in figures, some features are notable in a comparative perspective. Some of these are the high percentage of children born to unmarried parents, 65 per cent, and the high percentage of employed mothers. ${ }^{17}$ Couples, as well as single women, are entitled to assisted reproduction within the Swedish health system. Surrogacy is not permitted in Sweden. Paternity may be, however, established for fathers of children born to surrogacy-mothers abroad. ${ }^{18}$ As will be discussed below, equality for parents and prospective parents have been paramount in the development of the law. In current amendments of Swedish family law, the child's right to knowledge

15 Case of McMichael v the United Kingdom App no 16424/9o (ECtHR, 24 February 1995). See further Elisabeth Gording Stang, 'The Child's Right to Protection of Private Life and Family Life' in Said Mahmoudi and others, Child-friendly Justice: A Quarter of a Century of the UN Convention on the Rights of the Child (Brill Nijhoff 2015).

16 I am indebted to Professor John Asland for his insightful discussion on this topic at the 20th Nordic Family Law Seminar 25-26 May 2018. See also Kirsten Ketscher, 'Relationsret - en ny retsvidenskabelig optik?: Fra ægteskabs- og familieret mod en inkluderende relationsret' (2012) 35 Retfaerd 81-98; Erik Mägi and Lina-Lea Zimmerman, Stjärnfamiljejuridik: Svensk familjelagstiftning ur ett normkritiskt perspektiv (Gleerups 2015).

17 The Family Law and Parental Support Authority, Statistics on family law 2017 (28 June 2018) Art No 2018-6-2. <http://www.mfof.se/en/english/> accessed 12 December 2018; Ylva Nowak and Heléne Thomsson, 'Motherhood as idea and practice: A discursive understanding of employed mothers in Sweden' (2001) 15 Gender \& Society 407-428. See also Johanna Schiratzki, Barnrättens grunder ( 7 edn, Studentlitteratur 2019); Johanna Schiratzki, Mamma och papa inför rätta (Iustus 2008).

18 Titti Mattsson and Lotta Dahlstrand, 'Erkännande av föräldraskap vid assisterad befruktning utomlands' (Blendow Lexnova Expertkommentar - Familjerätt 2018). 
of his or her (genetical) origins is given a lot of attention in relation to the establishment of paternity and adoption. ${ }^{19}$

Around 50 per cent of all children experience parental separation during childhood. Approximately one-third of all children with separated parents are perceived to have dual residence, in other words, share their time between parents' households. ${ }^{20}$ As a main rule, parents have joint custody after a separation, which is the case for over 70 per cent of children. ${ }^{21}$ According to the Swedish interpretation of joint custody, both parents should agree on decisions necessary for the up-bringing of the child. ${ }^{22} \mathrm{~A}$ child's right to autonomy in relation to the custodian's responsibilities, as well as according to procedural law, is challenging to pinpoint down. ${ }^{23}$ Procedural law does not grant children under 18 years the right to litigate (talerätt) in, for example, court disputes on adoption and custody. In other areas, such as paternity and compulsory care, the child has a formal right to litigate (talerätt). Given that the child lacks procedural capacity (processbehörighet), the child is dependent on his or her custodian or guardian as legal representative. ${ }^{24}$

\section{3} Lack of Common Legal Concepts for the Establishment of Family

Swedish law recognises two ways for a child to get legal parents. These are either by establishing legal paternity and maternity in connection with the birth of a child or by adoption.

19 Legislative Bill 2017/18:121 (Prop. 2017/18:121 Modernare adoptionsregler); Legislative Bill 2017/18:155 (Prop. 2017/18:155 Modernare regler om assisterad befruktning och föräldraskap). See also Swedish Government Offical Reports 2018:68 (sou 201 8:68 Nya regler om faderskap och föräldraskap).

20 Swedish Government Official Reports (SOU 2011:51 Fortsatt föräldrar - om ansvar, ekonomi och samarbete för barnets skull).

21 Statistiska centralbyrån, 50 ooo barn är med om en separation varje år (2013).

22 Chapter 6, section 13 the Parental Code. See also chapter 6, section13 of the Parental Code. Suggestions for amendments in legislation relating to custody and to the right of the child to 'enjoy the company' of his or her parents has not led to legislation. Swedish Government Official Reports 2015:71 (SOU 2015:71 Barns och ungas rätt vid tvångsvård. Förslag till ny LVU); Swedish Government Official Reports (sou 2009:68 Lag om stöd och skydd för barn och unga $[L B U]$ ); Swedish Government Official Reports (sOU 2007:52 Beslutanderätt vid gemensam vårdnad m.m.).

23 See Pernilla Leviner, 'Voice but no Choice - Children's Right to Participation in Sweden' in Trude Haugli and others (eds), Children's Constitutional Rights in the Nordic Countries (Brill 2019).

24 From the age of 15 years, children have procedural capacity in litigation on compulsory care. 
The establishment of paternity and maternity for a child are not expressively covered in the Swedish Instrument of Government. Instead, these issues are regulated by legal acts such as the Parental Code, Act on Genetic Integrity, and Act on Personal Names. ${ }^{25}$ As a main rule, a person is recognised as a mother when giving birth to a child, and as a father if having contributed his sperm. In case a child is born after assisted reproduction, in accordance with Swedish law, a person who has consented to the treatment on the to-be-mother is considered a father or a parent. The consent then replaces a genetic link.

During 2018 and 2019, comprehensive amendments were made to the Parental Code regarding establishment of paternity (chapters 1-3 Parental Code) as well as adoption (chapter 4 Parental Code). ${ }^{26}$ Common to these amendments are a strong emphasis on the child's right to know his or her genetical origin in accordance with article 7 the CRC. In addition, the amendments meet adults' wishes for parenthood and respect for gender identity and sexual orientation, including gender changes. ${ }^{27}$ The amendments have led to the regulation on establishment of family, as the Swedish Council on Legislation (Lagrådet), has pointed out, becoming hard to get an overview of, and arguably, to apply. ${ }^{28}$ An example is the terminology in chapters $1-3$ of the Parental Code, which appears to be inconsistent with both traditional language and the concepts used in other chapters of the Parental Code, as well as in other Swedish legal Acts. The following terms and definitions are now to be found in the Parental Code: 29

MOTHER this could be either (a) a woman who gives birth to a child; or (b) in the case of changed gender, a woman who has contributed with sperm or have agreed to assisted conception with donor germs. However, the legal position of the spermcontributing-mother or the mother that has agreed to assisted conception with donor germs is covered by legal rules regarding paternity.

FATHER this could be either (a) a man who is covered by the presumption for paternity of the child of a married woman, has acknowledge paternity or has consented to assisted conception

\footnotetext{
25 Parental Code (föräldrabalken; 1949:381) the Act on Genetic Integrity (lag 2006:351 om genetisk integritet) and the Act on Personal names (lag 2016:1 030 om personnamn).

26 Chapters 1 and 4 of the Parental Code.

27 Legislative Bill 2017/18:121; Legislative Bill 2017/18:155.

28 Legislative Bill 2017/18:155.

29 Chapter 1 , sections $10-15$.
} 
outside the body of a woman whom he is married to or living with; or (b) in the case of a changed gender, a man who gives birth to a child. However, the legal position of a father who gives birth to a child is covered by legal rules regarding maternity.

PARENT (a) a woman who is the mother's spouse, registered partner or cohabitant and has consented to assisted conception (Ch. 1, Sec. 9 Parental Code); or b) a gender-neutral term covering parenthood for men and women (e.g. Ch. 1, Sec. 15 Parental Code on the child's right to knowledge about its parents).

Thus, the well-established, highly gendered, concepts 'mother' and 'farther' are used inconsequently in that a person termed 'father' are dependent on rules for 'mothers', regarding i.e. social benefits, and vice-versa. Likewise, the concept of 'parent' is used inconsequently; either designating a female partner of a birth-mother or as a gender-neutral term for parenthood.

As of 2019 consent to assisted reproduction with donated sperm may constitute grounds for paternity when the assisted reproduction is carried out abroad, provided that the treatment has been performed at a competent institution and that the child is entitled to take part of the sperm donor data. As a consequence of the new rules it has been suggested that paternity should be lifted if these conditions are not fulfilled, e.g. if the child's right to know the donor's identity cannot be met by the competent institution abroad. ${ }^{30}$ It is unclear how this broad possibility to revoke paternity correspond to the child's right of family life understood not only as a right to know about its genetic origins but also to be cared for by legally recognised parents especially when a de facto family relation is established.

An issue that may be closely connected with paternity is a child's right to citizenship, which is covered by the Constitution. ${ }^{31}$ Chapter 2 , section 7 of the Instrument of Government states the following: ${ }^{32}$

No Swedish citizen may be deported from or refused entry into the Realm. No Swedish citizen who is domiciled in the Realm or who has previously been domiciled in the Realm may be deprived of his or her citizenship. It

$30 \quad$ SOU 2018:68 Nya regler om faderskap och föräldraskap.

31 Rebecca Thorburn-Stern, 'Vem får del av kakan? Om migranter, rättigheter och solidaritet' in Thomas Erhag, Pernilla Leviner and Anna-Sara Lind (eds), Socialrätt under omvandling (Liber 2018) 169 .

Translated in Isberg (n 2). 
may however be prescribed that children under the age of eighteen shall have the same nationality as their parents or as one parent.

Children's right to citizenship may thus depend on their parents. ${ }^{33}$ This dependency may not, according to the Swedish Supreme Court, be interpreted in the negative. In other words, a withdrawal of Swedish citizen's paternity should not affect citizenship. The Supreme Court have in the cases NJA 2014 P. 323 and NJA 2018 p. 103 found the Swedish State to be bound to pay compensation for wrongfully withdrawing citizenship as a consequence of a withdrawal of paternity.

\section{Adoption—Consent from the Child but Not from Birth Parent}

The legal position of a child's birth parents has been weakened by the 2018 amendments on adoption. An adoption may now be granted without consent of a parent with custody if that parent is absent, has a severe physical or psychological medical condition that prevents consent or if there are otherwise special reasons. What would constitute special reasons are not spelled out in the legislative bill. According to the legislative bill introducing the amendments, the possibility to pass an adoption of a child without the consent of a parent with custody is primarily intended for international adoptions. According to the Chapter 4 of the Parental Code, however, all adoptions of children, national as well as international, are covered. An adoption may not be granted without the consent of the child if the child has reached the age of 12 years. It is labelled a 'valve'. The exception should only be applied in exceptional cases when it would appear 'objectionable' if an adoption was not approved. ${ }^{34}$ What that would be remains for the courts to determine.

The amendments could be described as a paradigm shift in Swedish law, as it is, in fact, introducing forced adoptions. The amendment that allows for a child to be adopted without the consent of a parent with custody was added late in the legislative process and has not been being circulated for formal consultation in the referral procedure of Swedish law-making. Nor has there been a public debate on the issue. This far-reaching change in the protection of right to family life was passed at time when very few children - less than 600 - a year were adopted. ${ }^{35}$

33 Section 2 of the Swedish Citizenship Act (lag 2001:82 om svenskt medborgarskap).

34 Legislative Bill 2017/18:121 $15^{2}$.

35 In 2017,240 children were placed for adoption through authorised organisations in 2017 (Legislative Bill 2017/18:121 95). An additional 21 applications for international 


\section{$5 \quad$ How Many Parents May Be Included in Family Life?}

Swedish law is incoherent in its view on the number of parents that are considered to be in a child's best interests to have. With regard to the establishment of a family through adoption or assisted conception one parent is accepted: ${ }^{36}$

That the child has one legal parent instead of two means an increased social and economic vulnerability for the child, e.g. if the parent becomes sick or dies. However, this does not mean that the child generally has a poorer upbringing than children who have two parents from birth.

One parent is thus accepted when establishing a family through assisted reproduction or adoption, whereas two parents are the norm in most other situations. In some areas of Swedish child law, such as custody, the right to family life of a child is understood as a right to have two parents, preferably as custodians, regardless of if the parents are living together in a traditional nuclear family or in separate households. ${ }^{37}$

In other areas of law, e.g. adoption, the interpretation of children's right to family life as including two parents is not upheld. Custody may not be shared between the foster parents and birth parents, nor may it be bestowed on more than two persons. In the public debate it has been suggested that to recognise parental rights for more than two persons would help to give children a more stable and secure childhood. It is argued that this would be the case for children in so-called step-families, same-sex relations and foster care. ${ }^{38}$

\section{$6 \quad$ Right to Family Life in Post-Divorce Families}

For a parent to have comprehensive legal rights and duties, in relation to his or her child, under Swedish law, the parent most have part in the custody. In the

adoption of children was processed by the Authority for family law and parental support. In addition, around 300 Swedish children were adopted (Sw. Myndigheten för familjerätt och föräldraskapsstöd).

36 Legislative Bill 2014/15:127 (Prop. 2014/1 5:1 27 Assisterad befruktning för ensamstående kvinnor) 12. Translation by the author.

37 Pernilla Leviner, 'Kärnfamiljsideal och fri familjebildning: oförenliga utvecklingsspår i den svenska familjerätten?' (2016-17) 3 Juridisk tidskrift 625-642.

38 Anna Singer, 'En, två, ett par eller flera?: föräldraskap i det 21:a århundradet' (2002) Svensk Juristtidning 377-389; Johanna Schiratzki, ‘Förslag kan ge fler övergrepp' Svenska dagbladet (2 March 2016). 
context of post-separation, the interpretation of the best interests of a child as having two parents is quite strongly upheld. ${ }^{39}$ In line with this understanding of the right to family life, shared custody, shared residence or contact arrangements are encouraged in the Parental Code, as well as in the in case law and by the social welfare committee. The paramount argument for doing so is the child's right to family life. ${ }^{40}$ The child's right to contact should not override the child's right to protection against maltreatment and other risks. In practice, however, it may be hard to properly assess the risks. It is further hard to assess the importance of the opinions of especially younger child, as guidelines and court praxis are lacking.

The Supreme Court has in case NJA 2017 p. 557 given a 16-year-old's opinions considerable weight with regard to liability for arbitrary handling of a child (egenmäktighet med barn) according to the Penal Code ${ }^{41}$ and custody according to chapter 6 of the Parental Code.

The child in case NJA 2017 p. 557 was at the time of Supreme Court's judgment, 16-year-old. She had three years earlier when her parents had joint custody been retained in Norway by a parent without the consent of the other. The Swedish Supreme Court held that child abduction and retention normally is considered inconsistent with the best interests of the child. Given the age of the child and her consequent position not to meet with her parent in Sweden, the Supreme Court found that the retaining parent could not be held liable for not returning the teenager against her explicit wishes. Neither did the Supreme Court consider it reasonable to expect the retaining parent to do more to make the child change her mind.

Issues on custody are to be decided in accordance with the best interests of the child. The understanding of the best interests of child and the right to family life are closely connected. The principal interpretations of the best interests of the child are to protect the child against harms and for the child to maintain close relations to both parents. ${ }^{42}$ The right to family life understood as the parents and children seeing each other may depend on the parents' ability to co-operate.

39 For example, Maria Eriksson, 'Contact, shared parenting, and violence: children as witnesses of domestic violence in Sweden' (2011) 25 International Journal of Law, Policy and the Family $165^{-183}$.

40 Swedish Government Official Reports 2017:6 (sou 2017:6 Se barnet!).

41 Chapter 7, section 4 of the Penal Code (brottsbalken; 1962:700).

42 Chapter 6, section 2a of the Parental Code. The paramount argument for doing so is the child's right to family life. The right to family life understood as the parents and children seeing each other may depend on the parents' ability to co-operate. 
A child's healthy attachment to his/her parent(s) is presumed to enable the child to establish new emotional bonds to a potentially quite large group of people, i.e. parents' current and former partners and their children. These relations are not covered by the Parental Code or any other legal Act. ${ }^{43}$ Therefore, this heterogenous group of a child's potential de facto family members have no legal obligation to care for the child, nor a right to initiate litigation. By way of protecting de facto family relations between an adult and a child, the social welfare committee (socialnämnden) may on behalf of the adult initiate proceedings on contact (chapter 6 , section 15 a, the Parental Code).

A child may be placed with foster parents in accordance with the Social Service Act (Socialtjänstlag; 2001:453) or following a compulsory care order, as per the Care of Young Persons Act (Lag 1990:52 med särskilda bestämmelser om vård av unga). Foster parents are contracted by the social welfare committee to take care of the child. They do not have an independent legally recognised relation to the child. They may, however, with the passing of time, develop de facto family relations to the child. The de facto family relation may, in turn, be legally recognised by a court order transferring custody from the birth parents to the foster parents. The social welfare committee are to consider initiating such a transfer of custody when a child has lived with the same foster family for three years. ${ }^{44} \mathrm{~A}$ transfer of custody is considered to be a Swedish version of adoption of a child without consent from birth parents. ${ }^{45}$ In 2013, 259 cases of transfer of custody to foster parents was reported. ${ }^{46}$ The argument for transfer of custody to foster parents is to enhance the child's stability. For the child to have a right to contact with its family of origin, the birth parents may initiate court proceedings on contact. In other cases, the child contact with its family of origin depends on foster parents in their capacity of specially appointed custodians.

In Swedish case law, case NJA 2014 P. 307 from the Supreme Court and case HFD 2011 ref. 13 from the Supreme Administrative Court regard the interpretation of the best interests of the child when choosing between maintaining family relations for children in care in relation to biological parents or foster parents. In these judgments the Supreme Court, as well as the Supreme

\footnotetext{
43 Anna Singer, Föräldraskap i rättslig belysning (Iustus 2000).

44 Chapter 6, section 8, the Parental Code; chapter 6, section 8, the Social Service Act.

45 Swedish Government Official Reports 2015:71.

46 Swedish Government Official Reports 2015:71 621.
} 
Administrative Court, concluded that the best interests of the child should be understood as a right to continue the de facto ongoing relations, i.e. social relations with the foster parents where prioritised over the birth parents legal standing as holder of custody. The child's right to family life with the family of origin was not analysed by the Supreme Administrative Court.

A child placed in a foster family has a right to contact with his or her his family-of-origin according to the Social Services Act as well as the Care of Young Persons Act. The implementation of this right may, in many cases, depend on the ability of the parents as well as the social welfare committee to support contact between the family of origin and the child. Birth parents, as well as other next-of-kin, has testified that they, contrary to the intention of the law, have been kept at arms-length from children in out-of-home care by the social welfare committee and by foster parents. ${ }^{47}$

In the Case of S.J.P. and E.S. $v$ Sweden ${ }^{48}$ the European Court of Human Rights, in 2018 , found that a child's right to contact with his/her family of origin under article 8 of the ECHR be may be severely restricted without it constituting a breach to respect for private and family life when children are taken into compulsory care.

The case concerned three siblings taken into care in 2009. The Swedish courts had placed restrictions on the applicants' contact with the children. At the outset, there was a total prohibition on contact but this was eventually lifted and the latest order, issued in April 2015, allowed them contact rights of six hours every other month.

It is worth noting that the total prohibition on limited contact between children and parents was lifted after six months. The contact granted since April 2015, six hours every other month, is of a duration that appears consistent with rulings of Swedish court. However, the Administrative Supreme Court in the case HFD 2017 ref. 40 were the Administrative Supreme Court ruled that strong reasons are required for a total prohibition on contact between a child in foster care and birth parents. This also applies to so-called upbringing placements when it is not considered realistic that the child returns to the birth parent(s).

Regardless of these rulings, a child's right to family life in relation to foster parents has been construed as sometimes conflicting with a right to family

\footnotetext{
47 The Supreme Administrative Court, Judgement Case no 6o62-15, 17-o6-15; Johanna Schiratzki, 'Hur ska en vårdnadshavare göra för att få hem ett barn som varit placerat för samhällsvård?' (2015) 1 Juridisk tidskrift. 
life with the child's family of origin. ${ }^{49}$ The best interests of the child in care is frequently understood as exclusively dependent on the child's relations with the foster parents. ${ }^{50}$ This perception of the best interests of the child is in stark contrast to the understanding of the best interests in post-divorce families. In post-divorce families, children are supposed to be able to establish and maintain close relations with several other. ${ }^{51}$ For children in care, a close relation with the foster parents is presumed to exclude maintaining or re-building relations with the family of origin. ${ }^{52}$

\section{Right to Family Life and Compulsory Care-Different Impact of Child Testimony}

In Swedish court practice, children's right to family life in relation to compulsory out-of-home care frequently depend on issues of investigation and evidence, including information disclosed by a child potentially at risk of abuse. As is the case in relation to other legal issues with a bearing on the child's right to family life, such as custody, the importance of the views of the child is hard to assess. In the rulings of the Swedish Supreme Administrative Court, information from the child has been given quite different impact. An example is the Supreme Administrative Court's ruling in case HFD 2017 ref. 42. The case entails a six-year-old girl who had disclosed that her father often hit her and her siblings.

In HFD 2017 ref. 42 the parents denied that violence had occurred and there was no evidence available, apart from the testimony of the six-yearold. The parents agreed to receive support from the social welfare committee, but did not consent to the children being placed in out-of-home care. In view of the purpose of the legislation, the Supreme Administrative Court held that information of a younger child could alone be the basis for a decision on compulsory care.

49 Titti Mattsson, Rätten till familj inom barn- och ungdomsvården (Liber 2010); Pernilla Leviner, 'När kan och bör placerade barn flytta hem: en oklar balansering mellan återförening och stabilitet i tre processer' in Ann-Christin Cederborg and Wiweka WarnlingNerep (eds), Barnrätt: En antologi (Norstedts Juridik 2014).

$50 \quad$ Anders Broberg and Pia Risholm Motander (2006), 'Anknytning' in sou 2015:71 Barns och ungas rätt vid tvångsvård. Förslag till ny $L V U$.

$5^{1} \quad$ Legislative Bill 2005/06:99 (Prop. 2005/o6:99 Ny vårdnadsregler) 57.

$5^{2}$ The Svea Court of Appeal (Svea hovrätt) 2015-03-23, T 108327-13. 
Information from the six-year old was thus decisive for the decision on compulsory care of the child. This position could be contrasted with the case HFD 2014 ref. 46 decided by the Supreme Administrative Court three year earlier. In this case, information from a 15-year-old girl was disregarded.

In HFD 2014 ref. 46 a 15-year-old asylum-seeking girl disclosed that she was beaten by her father. She was temporarily placed with a foster family, with the consent of her father. It was undisputed that the father insisted on the girl should undergo gynaecological examination to find out if she was still a virgin. The girl had threatened to take her life if she had to return to Russia with her family. The Supreme Administrative Court held that compulsory care should not be granted. The fact that the girl was an asylum-seeker was considered by the Supreme Administrative Court to weaken her credibility with regard to the alleged abuse. Other circumstances brought forward by the social welfare committee were not considered enough for a care order.

The position of the Supreme Administrative Court in the case HFD 2014 ref. 46 seems hard to accommodate with article 2 the CRC, on the right to equal treatment:

States Parties shall respect and ensure the rights set forth in the present Convention to each child within their jurisdiction without discrimination of any kind, irrespective of the child's or his or her parent's or legal guardian's race, colour, sex, language, religion, political or other opinion, national, ethnic or social origin, property, disability, birth or other status.

It appears that the girl's status as an asylum-seeker was imperative to the conclusion of the Supreme Administrative Court that the family life of the 15-yearold should not be limited. The concerned raised by Leviner in this volume appears to be relevant in this area of child law as well. That is to say that there is a risk that 'perspectives and wishes [of children] are only included and taken into account when in line with what adults have already decided in individual cases and/or only an argument for what adults want when it comes to public decision-making. ${ }^{53}$

53 Leviner, 'Voice but no Choice' (n 23). See also, Lotta Dahlstrand, Barns deltagande i familjerättsliga processer (Juridiska institutionen, Uppsala universitet 2004). 


\section{Is the Child's Right to Family Life Only a Right Know His or Her Origins, but Not to Be Cared for}

The right to family life at the beginning of life, according to Swedish law, is made up by an intricate web of sometimes contradicting rights and duties of the child and the (presumed) parents. The 2018 and 2019 amendments of the Swedish Parental Code regarding adoption and establishment of paternity aim at strengthening the child's right to know his or her genetical origin in line with article 7 the CRC. Less is said concerning the child's right to be cared for by his or her parents.

A child's right to knowledge, according to article 7 of the CRC, does not necessarily correspond to a right to family life understood as a right to be cared for. The child's right to be cared for by his or her parents - defined as men or women recognised as mothers, fathers or parents under Swedish law - has not been co-ordinated with the far-reaching principal changes on how to become a parent. The result may be described as prioritising a child's right to know 'who one is' over the right to have legally recognised relations to a father, mother or other parent. An example is the suggestion to revoke established paternity for children conceived with donated sperm in institutions abroad on the grounds that the child is at some point, after the establishment of paternity, no longer entitled to take part of the sperm donor data. Such a discourse appears to jeopardise the child's right to family life understood as a right to be cared for by, once, legally recognised parents especially when a de facto family relation is established. The understanding and protection of this aspect of a child's right to family life has proven more challenging.

The challenge of protecting the child's right to family life cannot be met by constitutional rights alone, nor by human rights' convention. On the contrary, it takes careful legal craftmanship to create a comprehensive legal system that meets the demands of protecting and promoting those relations that make up contemporary family life. Given, however, recent developments in family law, which are characterised by speed, rather than careful consideration, it appears that a constitutional right to family life might help to give time for such considerations and cautious craftmanship.

\section{References}

Broberg A and Risholm Motander P (2006), 'Anknytning' in sou 2015:71 Barns och ungas rätt vid tvångsvård. Förslag till ny $L V U$.

Cederborg A-C and Warnling-Nerep W (eds), Barnrätt: En antologi (Norstedts Juridik 2014). 
Dahlstrand L, Barns deltagande i familjerättsliga processer (Juridiska institutionen, Uppsala universitet 2004).

Dane L, 'Europadomstolen och barnets bästa' (2015) 2 Förvaltningsrättslig tidskrift 193224.

ECtHR, Guide on article 8 of the European Convention on Human Rights: Right to respect for private and family life, home and correspondence (Updated on 31 August 2018) <https://www.echr.coe.int/Documents/Guide_Art_8_ENG.pdf> accessed 12 December 2018.

Erhag T, Leviner P and Lind A-S (eds), Socialrätt under omvandling (Liber 2018).

Eriksson M, 'Contact, shared parenting, and violence: children as witnesses of domestic violence in Sweden' (2011) 25 International Journal of Law, Policy and the Family $165^{-183 .}$

Family Law and Parental Support Authority, Statistics on family law 2017 (28 June 2018) Art No 2018-6-2. <http://www.mfof.se/en/english/ $\geq$ accessed 12 December 2018.

Grahn-Farley M, 'Högsta domstolens rättighetspraxis från 2003 till 2015: utmaningar och möjligheter med en inkorporering av Barnkonventionen' (2017) Europarättslig tidskrift 651-669.

Isberg M, The Constitution of Sweden The Fundamental Laws and the Riksdag Act (Riksdagen 2016).

Ketscher K, 'Relationsret - en ny retsvidenskabelig optik?: Fra ægteskabs- og familieret mod en inkluderende relationsret' (2012) 35 Retfaerd 81-98.

Legislative Bill 1975/76:209 (Prop. 1975/76:209 om ändring i regeringsformen).

Legislative Bill 2005/06:99 (Prop. 2005/o6:99 Nyvårdnadsregler).

Legislative Bill 2009/10:80 (Prop. 2009/10:80 En reformerad grundlag).

Legislative Bill 2014/15:127 (Prop. 2014/15:127 Assisterad befruktning för ensamstående kvinnor).

Legislative Bill 2017/18:121 (Prop. 2017/18:121 Modernare adoptionsregler).

Legislative Bill 2017/18:155 (Prop. 2017/18:155 Modernare regler om assisterad befruktning och föräldraskap).

Leviner P, 'Voice but no Choice - Children's Right to Participation in Sweden' in Trude Haugli and others (eds), Children's Constitutional Rights in the Nordic Countries, (Brill 2019).

Leviner P, 'Kärnfamiljsideal och fri familjebildning: oförenliga utvecklingsspår i den svenska familjerätten?' (2016-17) 3 Juridisk tidskrift 625-642.

Leviner P, 'När kan och bör placerade barn flytta hem: en oklar balansering mellan återförening och stabilitet i tre processer' in Ann-Christin Cederborg and Wiweka Warnling-Nerep (eds), Barnrätt: En antologi (Norstedts Juridik 2014).

Lind A-S and Namli E (eds), Mänskliga rättigheter i det offentliga Sverige (Studentlitteratur 2017).

Mahmoudi S and others, Child-friendly Justice: A Quarter of a Century of the UNConvention on the Rights of the Child (Brill Nijhoff 2015). 
Marcusson L, 'Det offentliga uppdraget och de mänskliga rättigheterna' in A-S Lind and E Namli (eds), Mänskliga rättigheter i det offentliga Sverige (Studentlitteratur 2017).

Mattsson T, 'Constitutional Rights for Children in Sweden' in Trude Haugli and others (eds), Children's Constitutional Rights in the Nordic Countries (Brill 2019).

Mattsson T, Rätten till familj inom barn- och ungdomsvården (Liber 2010).

Mattsson T and Dahlstrand L, 'Erkännande av föräldraskap vid assisterad befruktning utomlands' (Blendow Lexnova Expertkommentar - Familjerätt 2018).

Mägi E and Zimmerman L-L, Stjärnfamiljejuridik: Svensk familjelagstiftning ur ett normkritiskt perspektiv (Gleerups 2015).

Nowak Y and Thomsson H, 'Motherhood as idea and practice: A discursive understanding of employed mothers in Sweden'(2001) 15 Gender \& Society 407-428.

Schiratzki J, Barnrättens grunder (7 edn, Studentlitteratur 2019).

Schiratzki J, 'Förslag kan ge fler övergrepp' Svenska dagbladet (2 March 2016).

Schiratzki J, Mamma och pappa inför rätta (Iustus 2008).

Schiratzki J, 'Hur ska en vårdnadshavare göra för att få hemmet ett barn som varit placerat för samhällsvård?' (2015) 1 Juridisk tidskrift.

Singer A, 'En, två, ett par eller flera?: föräldraskap i det 21:a århundradet' (2002) Svensk Juristtidning $377-389$.

Singer A, Föräldraskap i rättslig belysning (Iustus 2000).

Stang EG, 'The Child's Right to Protection of Private Life and Family Life' in S Mahmoudi and others, Child-friendly Justice: A Quarter of a Century of the UN Convention on the Rights of the Child (Brill Nijhoff 2015).

Statistiska centralbyrån, 50 ooo barn är med om en separation varje år (2013).

Swedish Government Official Reports 2007:52 (sou 2007:52 Beslutanderätt vid gemensam vårdnad m.m.)

Swedish Government Official Reports 2008:125 (sOU 2008:12 En reformerad grundlag del 1).

Swedish Government Official Reports 2009:68 (sou 2009:68 Lag om stöd och skydd för barn och unga $(L B U))$.

Swedish Government Official Reports 2011:51 (sOU 2011:51 Fortsattföräldrar-om ansvar, ekonomi och samarbete för barnets skull).

Swedish Government Official Reports 2015:71 (sOU 2015:71 Barns och ungas rätt vid tvångsvård. Förslag till ny $L V U)$.

Swedish Government Official Reports 2017:6 (sou 2017:6 Se barnet!).

Swedish Government Offical Reports 2018:68 (sou 2018:68 Nya regler om faderskap och föräldraskap).

Thorburn-Stern R, 'Vem får del av kakan? Om migranter, rättigheter och solidaritet' in Thomas Erhag, Pernilla Leviner and Anna-Sara Lind (eds), Socialrätt under omvandling (Liber 2018). 